\title{
Andreas Lehnardt Christian Influences on the Yahrzeit Qaddish
}

\section{Introduction}

It is well known that the qaddish prayer serves in the Ashkenazi rite primarily as a conclusion of the entire service, and as a closing element of its main sections. Additionally, it marks the ending of a Torah reading and is also recited after the study of religious texts. As reflected in early rabbinic literature, it may have developed from a prayer of so-called bet midrash origin. ${ }^{1}$ Today, however, it is mainly known as a prayer recited by mourners or one mourner during or at the end of the service, or after a burial. Since this usage is not attested in early rabbinic sources, it is certainly a later medieval development. ${ }^{2}$ Obviously, the text of the qaddish, which is known in at least four main versions - hași qaddish, qaddish shalem, qaddish de-rabbanan and qaddish le(it)haddeta - has undergone considerable changes, has been used from time to time in changing contexts, and could have fulfilled different purposes.

This article aims to shed light on the existence of the yahrzeit qaddish the latest development in these uses of the qaddish - as a custom for commemorating the anniversary of a parent's death, which seems to have emerged only in thirteenth-century Ashkenaz. To my knowledge the liturgical custom of saying qaddish on a yahrzeit, which should not be confused with the older and related custom of saying qaddish yatom (the orphan's qaddish), or the

1 On the early development of the qaddish as reflected in rabbinic literature, see: David de Sola Pool, The Old Jewish Aramaic Prayer: The Kaddish (Leipzig 1909, repr. New York: Sivan Press, 1964); Jacob Hübscher, Das Kaddisch-Gebet, dessen Sinn, Bedeutung und Tendenz erklärt und commentiert (Berlin: Cernauti, 1912); Joseph Heinemann, Prayer in the Talmud. Forms and Patterns, Studia Judaica 9 (Berlin: de Gruyter, New York, 1977), pp. 251-75; Andreas Lehnardt, Qaddish. Untersuchungen zur Entstehung und Rezeption eines rabbinischen Gebetes, Texts and Studies in Ancient Judaism 87 (Tübingen: Mohr-Siebeck, 2002).

2 Cf. Israel M. Ta-Shma, 'Some Notes on the Origins of Kaddish Yatom' in idem, Early FrancoGerman Ritual and Custom (Hebrew; Jerusalem: Magnes Press, 1994), pp. 299-310; Shmuel Glick, Or Le-Avel. Le-hitpatḥutam shel iqqare minhagei avelut be-mesorot Yisrael me-le-ahar haqevura ad tom ha-shiv'a (Efrat: Keren Ori, 1991), pp. 147-58; see also Lehnardt, Qaddish, pp. 278-95. On the recitation of the qaddish after burial, see also idem, 'Tzidduq Ha-Din und Kaddish. Beobachtungen zur Entwicklung der jüdischen Begräbnisliturgie im Mittelalter', Trumah. Zeitschrift der Hochschule für Jüdische Studien Heidelberg, 12 (2002), pp. 1-33. 
qaddish said after burial, ${ }^{3}$ has never been the subject of rigorous investigation. What can be found in articles and books on Jewish liturgy concerning the yahrzeit qaddish is marginal. ${ }^{4}$ This is rather surprising, since the custom is widely practised in all the Jewish liturgical rites, and the Middle-High German 'iar-zit' or the Yiddish 'Yohrzayt' 's undoubtedly one of the most famous German words in the Jewish world. Furthermore, the lack of interest is surprising because in the early nineteenth century Christian and Jewish scholars such as Gustav Dalman (1855-1941), 6 Israel Abrahams (1858-1924), ${ }^{7}$ Moritz Güdemann (1835-1918), ${ }^{8}$ and Jacob Obermeyer (1845-1935) ${ }^{9}$ were already hinting in articles and notes that some yahrzeit customs, like kindling a light, were inspired by, or adopted from Christian, or more precisely Catholic, mourning rites.

Remarkably, in publications that emerged from a more traditionally observant perspective, as in a Hebrew article by Avraham Hoffer, ${ }^{10}$ a certain interest

3 See on this also Andreas Lehnardt, 'Die Qaddish yitkele harba-Versionen und ihr Verhältnis zu biblischen Texten' in Orient als Grenzbereich? Rabbinisches und außerrabbinisches Judentum, ed. by Annelies Kuyt and Gerold Necker (Wiesbaden: Harrassowitz, 2007), pp. 51-64.

4 See, e.g., Eliezer (L.) Landshut, Vollständiges Gebet- und Andachtsbuch zum Gebrauch bei Kranken, Sterbenden und Leichenbestattungen sowie beim Besuchen der Gräber von Verwandten und Lieben (Hebrew; Berlin, Adolf 1867), p. LXVI; Adolf Kurrein, Das Neschamoth-(Seelen)Licht. Eine Abhandlung (Frankfurt a.M.: J. Kauffmann, 1898), pp. 27 ff.; Kaufmann Kohler, 'Kaddisch-Gebet, Jahrzeit und Seelen-Gedächtnißfeier', Jewish Reformer, V,1 No. 11 (1886), pp. 11-12; Y. L. Avida (Zlotnik), 'Perakim Be-'Inyane Ha-Azkara (Jahrzeit)', Sinai, 25 (1949), pp. 5968; 330-48; Maurice Lamm, The Jewish Way in Death and Mourning (New York: Jonathan David Publishers, 1969), pp. 201-06; J. S. Sperka, Hayye Nesah. Eternal Life. A Digest of all Jewish Laws of Mourning. Complete Funeral, Burial and Unveiling Services, Kaddish, Yizkor, and El Mohle in Hebrew, Translation and Transliteration (New York: Bloch, 1961), pp. 91-94; Isaac Klein, A Guide to Jewish Religious Practice, Moreshet 6 (New York: Ktav, 1979), pp. 294ff; Judith Hauptman, 'Death and Mourning: A Time for Weeping, a Time for Healing', in Celebration and Renewal, ed. by R. M. Geffen (Philadelphia: Jewish Publication Society, 1993), pp. 226-51, esp. p. 247.

5 Cf. M. Lexer, Mittelhochdeutsches Handwörterbuch (Leipzig 1872, repr. Stuttgart: Hirzel, 1974), p. 1476 s.v.; see also Uriel Weinreich, Modern English-Yiddish Yiddish-English Dictionary (New York: Schocken, 1977), p. 589 s.v.

6 Gustav Dalman, 'Jüdische Seelenmesse und Totenanrufung', Saat auf Hoffnung, 27 (1890), pp. 69-190.

7 Israel Abrahams, Jewish Life in the Middle Ages (Philadelphia 1896, repr. Philadelphia, Jerusalem: Jewish Publication Society, 1993), p. 140 n. 2.

8 Moritz Güdemann, Geschichte des Erziehungswesens und der Cultur der Juden in Deutschland während des XIV. und XV. Jahrhunderts, Vol. 3 (Vienna, 1888, repr. Amsterdam: Philo Press, 1966), p. 132.

9 Jacob Obermeyer, Modernes Judentum im Morgen- und Abendland, Vienna (Leipzig: C. Fromme, 1907), pp. 126-28.

10 Avraham Hoffer, 'Yesodo u-meqoro shel yom mitat ha-av we-ha-ben mi-de shana beshana', Ha-Zofe le-Hokhmat Yisrael, 10 (1926), pp. 116-21. 
prevails in explaining all Jewish anniversary customs on the basis of earlier Jewish sources. For example, Hoffer stresses fasting on the anniversary of a death as a custom that was described in earlier rabbinic writings, ${ }^{11}$ and therefore understands all other related practices as having developed from this older rite. In studies written by more liberal authors, however, at least the term yahrzeit and some of the related minhagim are explained as the result of influences from the Christian environment in Ashkenaz in which they evolved. ${ }^{12}$

With an awareness that any inquiry in this field may be used polemically or apologetically, the current study aims to present suggestions regarding the possible historical development of the yahrzeit qaddish. The author intentionally limits his focus here to the prayer minhag of reciting qaddish, without tackling the questions of whether and how similar yahrzeit customs, like the kindling of lights, may be explained. ${ }^{13}$

\section{Where and when did this custom emerge?}

The information available for answering this question is scanty indeed. Encyclopaedia entries and academic articles yield different responses, and even the topic of who first used the term 'yahrzeit' has not yet been thoroughly researched. ${ }^{14}$ From the outset, one must distinguish between two related questions: who first mentioned the custom of reciting an additional qaddish at the end of the service on the anniversary of the death of a loved one; and who first used the name 'yahrzeit' to describe this practice.

11 Cf. bNed. 12a; 14a; bŠebu. 20a; Hoffer also refers to the older custom of fasting on the anniversary of the death of Gedalya (Șom Gedalya), cf. Jer. 40; 2 Kings 25.

12 For a review article that is remarkable in this regard, see P. Rieger on I. Elbogen, Der jüdische Gottesdienst in seiner geschichtlichen Entwicklung (Frankfurt a. M.: Kauffmann, 1913), Allgemeine Zeitung des Judentums, 78 (1914), p. 468.

13 On this, see Abrahams, Jewish Life, p. 140 n. 2; Steven Oppenheimer, 'The Yahrzeit Light', Journal of Halacha and Contemporary Society, 37 (1999), pp. 101-16; S. L. Silver, An Investigation into the Origins of Jahrzeit Practices, Rabbinic Thesis, Hebrew Union College 1984 (n.v.).

14 Cf. Jehuda D. Eisenstein, Art. 'Jahrzeit', Jewish Encyclopaedia 7 (1904), pp. 63-65; idem, Ozar Dinim u-Minhagim. A Digest of Jewish Laws and Customs in Alphabetic Order (Hebrew; Tel Aviv: Shilo, 1938), pp. 154 ff.; D. Flattau, Art. 'Jahrzeit', Encyclopedia Judaica (Deutsch) 8 (1931), pp. 779-81; L. I. Rabinowitz, Art. 'Yahrzeit', Encyclopaedia Judaica 16 (1971), pp. 702-3; see also: 'Yortsayt', The Oxford Dictionary of Jewish Religion, ed. R. J. Z. Werblowsky et al. (Oxford: University Press, 1997), p. 753; Abraham E. Millgram, Jewish Worship (Philadelphia: Jewish Publication Society, 1971), pp. 448 ff.; Catherine Hezser, Art. 'Jahrzeit', Religion in Geschichte und Gegenwart 4 (2001), pp. $351 \mathrm{f}$. 
It has often been noted that Ya‘aqov ben Moshe Moellin (c. 1360-1427), better known by his acronym 'Maharil', the leading rabbinic authority of central Europe in the fourteenth century, seems to have been the first to mention the custom of saying qaddish on the anniversary of the death of a father or a mother. ${ }^{15}$ One should, however, recall that his Sefer Maharil was compiled only later by one of his students, Rabbi Zalman of St. Goar, and printed even later, in Italy in 1556. Furthermore, the term yahrzeit does not appear in his book. The only portion that refers to the commemoration of the anniversary of a death leaves open the question of whether the qaddish said on a yahrzeit should be differentiated at all from the 'usual' qaddish yatom.

The passage in Sefer Maharil that is of interest for this study alludes only to the problem of who would be the appropriate person to say qaddish during a Sabbath service when there are visitors from another community who are present and may also wish to say qaddish. Sefer Maharil does not discuss whether this additional qaddish by a mourner after an eleven- or twelve-month period could be interpreted as a sign of disrespect. Neither does it mention the effect of this qaddish on the souls of the dead. Its sole focus is on the dilemma concerning the synagogal presence of more than one mourner obligated to honour the yahrzeit of a parent. ${ }^{16}$

Additionally, there is evidence from the responsa of the "Maharil'17 that some people would recite this form of qaddish - which is today called the yahrzeit qaddish - twice in a leap year, if the anniversary of the parent's death fell during Adar I. ${ }^{18}$ But in a short comment in a responsum by the 'Maharil', which has been attributed to Rabbi Yehuda he-Hasid and resembles a similar remark in Sefer Hasidim, ${ }^{19}$ the term yahrzeit is not mentioned. It therefore seems that R. Ya'aqov Moellin knew the custom of an additional recitation of

15 Cf. The Book of Maharil. Customs by Rabbi Ya'aqov b. Moshe Moellin. Published According to the First Edition with Additions and Variants from Various Manuscripts with References, Notes, and Indices, ed. by Shlomo Y. Spitzer (Jerusalem: Makhon Yerushalayim, 1991), p. 608, where it is mentioned that one is obligated to say qaddish on an anniversary only once; the term 'yahrzeit', however, is not used. See also pp. $446 \mathrm{ff}$.

16 On the custom of saying qaddish for only eleven instead of twelve months, the estimated time of being judged in Gehenna (cf. $m^{`} E d$. 2.10), which was inspired by the Zohar, cf. Obermeyer, Judentum, p. 123; Ismar Elbogen, Jewish Liturgy. A Comprehensive History (New York, Jerusalem: The Jewish Publication Society, 1993), p. 408 n. 9; Lehnardt, Qaddish, p. 279 n. 6. 17 See Responsa of Rabbi Ya'aqov Moellin-Maharil. Revised and Corrected with Additions According to Previous Editions and Various Manuscripts with Introduction, References, Notes, and Commentaries, ed. by Y. Satz (Jerusalem: Makhon Yerushalayim, 1979), p. 29 (§39).

18 On this problem, see eg, Hübscher, Kaddisch-Gebet, p. 42.

19 Cf. Sefer Hasidim she-Hibber Rabbenu Yehuda he-Hasid, ed. by Reuven Margaliot (Jerusalem: Mossad Harav Kook, 1957), p. 440 (§ 712). 
qaddish yatom by a mourner on anniversary of a death, but he did not call it 'yahrzeit', nor did he ascribe to it any new religious intent, as in subsequent kabbalistic writings.

Caution is, however, essential lest the conclusions drawn from this observation be too far-reaching. The term yahrzeit can already be found in the writings of a teacher of the 'Maharil', namely in the responsa of the Austrian, Rabbi Shalom of Wiener Neustadt ${ }^{20}$ who died in 1415/16. According to Shlomo Spitzer in his edition of the responsa of Shalom of Neustadt, it is here that one finds the first mention of yahrzeit, and not, as is often claimed, in a responsum by Moshe Mintz (fifteenth century), nor in a statement erroneously ascribed to Meir of Rothenburg. ${ }^{21}$ Yet in the responsum of Shalom of Neustadt, yahrzeit refers only to fasting on the anniversary of a dead relative, but not to the yahrzeit qaddish. And the same holds true for the occurrences of the word yahrzeit in the minhag book written later by Yiṣhaq of Tyrnau (who died no earlier than 1408). ${ }^{22}$ This famous Austrian rabbi also mentions yahrzeit in relation to fasting, but without connecting this with the recitation of qaddish on that specific day. ${ }^{23}$ It may therefore only be surmised that he, like his teacher Shalom, knew the custom only from oral tradition, probably assuming that the yahrzeit qaddish should be recited only as an additional qaddish yatom.

The next scholar to use the term yahrzeit in connection with mourning customs seems to have been the great Eastern European talmudist and kabbalist, Mordekhai ben Avraham Jaffe (c. 1535-1612) in his Levush Tekhelet on the Arba'a Turim (Berdiczew, 1821, §133). It should, however, be noted that already in his teacher's main work, Darkhei Moshe (printed in Fürth in 1766), a commentary on Ya'aqov ben Asher's Turim written by Moshe Isserles (c. 1525-72, acronym: 'Rema'), it is explained that 'in the case of a yahrzeit, qaddish may

20 Cf. Decisions and Customs of Shalom of Neustadt, ed. by Sh. Spitzer (Jerusalem: Makhon Yerushalayim, 1977) (Hebrew), § 457.

21 See on this Abraham Berliner, 'Die mittelhochdeutsche Sprache bei den Juden', Jahrbuch für jüdische Geschichte und Literatur, 1 (1898), pp. 162-82, esp. p. 164: 'Seit den Zeiten des R. Meir aus Rothenburg wird das Wort ,Jahrzeit' in jüdischen Quellen bekannt, das dann sich so sehr eingebürgert, daß man es nur als eine specielle jüdische Bezeichnung erkennen mag.' Cf. on this, however, Avida, Sinai, 25 (1949), p. 56. On Mintz (sometimes spelled: Münz), cf. also Jakob Zimmels, Studies in Jewish History and Booklore (New York: JTS New York, 1944), pp. 119-27.

22 Cf. Sefer Ha-Minhagim (Rulings and Customs) of Rabbi Eisik Tirna Published according to the First Edition with Additions and Variants of Various Manuscripts with Introduction, References, Notes, and Commentaries, ed. by S. J. Spitzer (Hebrew; Jerusalem: Makhon Yerushalayim, 1979). See also Eisenstein, Art. 'Yahrzeit', p. 64, who suggests that Yiṣhaq Tyrnau was the first who used the term 'yahrzeit'.

23 Cf. his Sefer Ha-Minhagim, ed. by Spitzer, p. 119 n. 1 on $\S 183$. 
be recited even when the anniversary falls on a Sabbath'. ${ }^{24}$ This is an opinion that the Rema, like earlier authorities, connects with the legend about a dead man's son who was ordered by Rabbi Akiva to say qaddish, the well known founding legend for reciting the orphan's qaddish. ${ }^{25}$

Evidently, all these early sources for the recitation of qaddish by a relative on the anniversary of a death reflect the close linkage between qaddish yatom and the older custom of fasting on a yahrzeit. Furthermore, all these references are found in Ashkenazi writings, namely, in texts that originated in southern Germany or in Austria and were written at the beginning of the fourteenth century.

An important witness to this change in attitude towards qaddish in Ashkenaz is Binyamin Ze'ev ben Matitya of Arta, the early $16^{\text {th }}$ century Greek halakhic scholar, who writes in his Shu” t Hinukh bet Yehuda. ${ }^{26}$

It is correct with regard to fasting (on yahrzeit) that it is an important thing ... but saying qaddish (on yahrzeit) is only a local custom in those lands (i.e. Ashkenaz), and it is not (a custom) in other places, (which means) in the land of Yishma'el.

A similar reference to the Ashkenazi origin of the yahrzeit qaddish is found in a famous passage in Menashe ben Yisrael's (1604-57) Nishmat Hayyim. ${ }^{27}$ This celebrated Sefardi writer and resident of Amsterdam makes abundantly clear that yahrzeit qaddish was not only a disputed Ashkenazi custom but also a minhag that found many opponents. Being Sefardi and a kabbalist, he seems to have been reluctant to adopt this custom. Nonetheless, he is probably the first writer who tries to have this practice adopted among non-Ashkenazi congregations. Underlying his position, he cites Yedidya Gottlieb ben Avraham's Lewiat Ha-Derekh, printed in Cracow in 1644, providing a completely new explanation of this liturgical usage of the qaddish that was originally ascribed to Yiṣhaq ben Shelomo Luria Ashkenazi (c. 1510-74), the famous kabbalist from Safed. Gottlieb ben Avraham writes:

24 Cf. D. Telsner, The Kaddish. Its History and Significance (Jerusalem: Tal Orot Institute, 1995), p. 229.

25 Cf. the version of this ma'ase in: Sefer Or Zarua', hibbero ga'on tif'eret hakhmei Yisrael R. Yișhaq ben Moshe mi-Wina, ed. by Abraham Lehrn, Vol. 2 (Zhitomir 1862, repr. Benei Braq: Hekhal Ha-Sefer, 1958), pp. 11c-d; the dating and origin of this story are disputed, cf. Myron B. Lerner, 'Ma'ase Ha-Tanna We-Ha-Met. Gilgulaw ha-sifrutiim we-ha-hilkhatiim', Asufot, 2 (1988/89), pp. 29-70; Rela Kushelewsky, 'Ha-Tanna We-Ha-Met ha-Noded: ha-omnam aggada lo yehudit?', Criticism and Interpretation, 30 (1994), pp. 41-63.

26 Amsterdam 1708, §83.

27 Menashe ben Yisrael, Sefer Nishmat Hayyim (Leipzig 1862, repr. Tel Aviv, 1968), p. 55a (II 27) = Idem, Sefer Nishmat Ḥayyim Ha-Menuqqad (Jerusalem: Yedid Ha-Sefarim, 1995), p. 150. 
The sages of Eretz Yisrael complain about the minhag that exists in our lands (ie Ashkenaz), that we say qaddish on the anniversary of the death of a father and a mother, what we call in German 'yahrzeit', from year to year (ie every year). And [this custom] appears to mock [the dead], because the Sages ordained saying qaddish for a period of only eleven months and not more, so that one's father should not look like a wicked person, [given that] the judgement in Gehenna lasts twelve months. And if this would be a (correct use of the qaddish) when one's father or mother has died, how can one hold (his father) to be a wicked man for several years, saying qaddish (all that time) for him, to release him from the punishment in Gehenna. Would this not shame his father? And according to our ways it is correct, for the intention (of saying qaddish on the anniversary is) to elevate the (souls of the) righteous from one level to the next.

The 'new' idea referred to in this statement is that a qaddish said on a yahrzeit not only atones for the sins of the deceased relatives in Gehenna but also elevates the souls to higher spheres in Gan 'Eden. This understanding of the yahrzeit-qaddish, nowhere mentioned in the legend about Rabbi Akiva and the dead man's son, must be understood against the background of Lurianic Kabbala and its mythic messianism of tiqqun. According to Sefer Ha-Kawwanot, written by a disciple of Luria, prayers like the qaddish not only save one's soul from Gehenna but they are also effective in raising souls from the lower levels of Gan 'Eden to the upper ones. ${ }^{28}$

The Lurianic explanation referred to by Gottlieb ben Avraham and Menashe ben Yisrael reflects, then, how in later times (ie a significant period after Ya‘aqov Moellin's writings) kabbalistic narratives offered to balance the conflicting traditions of limiting the recitation of qaddish yatom to the first eleven months after the death of a relative and of saying an additional qaddish on the anniversary of the death each year. This kabbalistic interpretation seems to have been one of the main reasons for the ultimate acceptance of the yahrzeit qaddish among Oriental, Italian and Sefardi Jews. ${ }^{29}$ This stance was also later strengthened because the yahrzeit qaddish was introduced in a gloss by Moshe Isserles to Shulhan 'Arukh, Yore De'a $(376,4) .30$ Opinions that remained

28 Cf. Yișhaq ben Shelomo [Ashkenazi] Luria, Sefer Ha-Kawwanot le-ha-Rav ha-Elohi qadosh yomar lo Yiṣhaq Luria (Korzec: Silberman, 1784), pp. 22b-23a. On the mystical interpretation of the qaddish by Luria, cf. also Siddur me-ha-AR'Y ha-Nikra be-Shem Kol Ya'aqov (Slavuta: Pavloitsch, 1804), pp. 51a-54b. On the importance of these interpretations of the qaddish, cf. D. Assaf, Sefer Ha-Qaddish (Haifa: Maimonides Research Institute, 1966), pp. $202 \mathrm{ff}$.

29 For the Italian rite, cf. A. Berliner, Gesammelte Schriften, Vol. 1: Italien (Frankfurt a. M.: Kauffmann, 1913, repr. Hildesheim, Zürich, New York: Olms, 1988), pp. 179 ff.; for the Sefardi communities, cf. Pool, Kaddish, p. 106 and H. J. Zimmels, Ashkenazim and Sephardim. Their Relations, Differences, and Problems as Reflected in the Rabbinical Responsa (London 1958, repr. Farnborough: Gregg, 1969), pp. $186 \mathrm{ff}$.

30 See Shulhan 'Arukh, Yore De'a, 376,4 [Hilkhot Avelut] (299b). On the reception of the word 'Yahrzeit' in oriental congregations, cf. also J. Press, 'Schebua Ha-Ben', Monatsschrift für Geschichte und Wissenschaft des Judentums, 76 (1932), pp. 572-77, esp. p. 576. See also Yiṣhạaq 
critical of the introduction of this custom may also be found in sources written long after this rather official statement of support in the Shulhan 'Arukh. ${ }^{31}$

\section{Christian 'influences'?}

What does Christianity have to do with these motivations for saying qaddish on a yahrzeit? Is it not somewhat odd to ask if the additional use of qaddish on the anniversary of a dead relative was influenced by Christianity? The question arises especially in the light of the previous analysis, which indicates that this custom is obviously connected with the development of qaddish yatom, a similar use of the qaddish usually assumed to have emerged in the Rhineland during the persecutions by the Crusaders in the eleventh century, with their lasting effects on liturgy and prayer?

It is significant that at the very time when various yahrzeit customs were being adopted by Ashkenazi Jews in the thirteenth and fourteenth centuries, comparable developments were also occurring in Catholic Christianity. Those changes seem to have been motivated on the one hand by the spread of diseases, such as the plague, and on the other hand by social conditions. Additionally, the commemoration of the deaths of relatives was a major field of concern in Christian churches from antiquity onwards. ${ }^{32}$ From the time of the early Church fathers, such as Polycarp, Tertullian and Cyprian, ${ }^{33}$ until the thirteenth and fourteenth centuries, the death of a relative or a saint would always have been commemorated and celebrated by special masses and

ben Shmuel Lampronti, Pahad Yiṣhaq. Real-Wörterbuch zum Talmud und den Dezisoren (Posekim), Vol. 10 (Hebrew; Lyck 1874), pp. 158a-b.

31 On this, cf., e.g. Y. Galis, Minhagei Ereș Yisrael (Jerusalem: Mosad Harav Kook, 1968), p. 63 (§25) on conflicts over the right to say qaddish in the qehillot of Amsterdam and London, where the yahrzeit qaddish was said only by a sheliah șibbur (see Rabbi Shem Tov Gaguin, Keter Shem Tov [Kidan 1934]); see also p. 312, on drawing lots to determine who has the right to say qaddish. On similar problems, see also W. S. Jacobson, Über das Qaddish-Gebet (Frankfurt a. M.: Verlag des Israelit; Hermon, 1932, repr. Basel: Goldschmidt, 1974), p. 52. For further material on discussions regarding who has the right to say yahrzeit qaddish, cf. Louis Jacobs, Theology in the Responsa (London, Boston: Routledge, Kegan, 1975), p. 273, on a responsum by Joseph Hayyim from Baghdad (1835-1909) which addresses the question of whether the yahrzeit qaddish is effective even twenty years after the death of a parent.

32 Cf. Reiner Kaczynski, Art. 'Gedenken der Toten', Lexikon für Theologie und Kirche3 4 (1995), p. 339; H.-J. Ignatzi, Art. 'Jahrgedächtnis', Lexikon für Theologie und Kirche 5 (1996), pp. 711 ff. 33 Cf. Peter Karpinski, Annua dies dormitionis. Untersuchungen zum christlichen Jahrgedächtnis der Toten auf dem Hintergrund antiken Brauchtums, Europäische Hochschulschriften XXIII 300 (Frankfurt a. M., Bern, New York: Lang, 1987). 
prayers. The commemoration rites of fasting, praying or celebrating a mass on the seventh or the thirtieth day following death, and on the anniversary, were rooted deeply in the belief that the deeds of the living could have a direct effect on the fate of the dead in their place - be it in hell, in a state of limbus, or in heaven.

In Christianity, however, these mourning customs were a pagan heritage, especially originating in Roman rites. Some Christian theologians succeeded in retroactively basing these practices on biblical examples and laws: for instance, with regard to the commemoration on the seventh, they relied on the law demarcating seven days of impurity after contact with a corpse; and in the case of the thirtieth day, they pointed to the bereavement period of thirty days for both Aaron and Moses - meaning the period of time the community spent mourning each of their deaths. Given the early stages of development of mourning customs, Christianity was clearly influenced by two spheres of belief: a Gentile and a Jewish one. ${ }^{34}$ After a long period of relative stability, with only slight changes in mourning rituals, we find in Christian sources, especially from the thirteenth century onwards, a new and strengthened interest in special prayers and masses for the dead. ${ }^{35}$ This renewed interest in masses for the dead parallels the invention of further customs of mourning like memorial donations, which gained a prominent place in the social, political and theological culture of the Catholic Church during the thirteenth and fourteenth centuries. ${ }^{36}$ As has been well researched in recent decades, these

34 Cf. on this Emil Freistedt, Altchristliche Totengedächtnistage und ihre Beziehung zum Jenseitsglauben und Totenkultus der Antike, Liturgiegeschichtliche Quellen und Forschungen 24 (Münster i. W.: Aschendorf, ${ }^{2} 1971$ ), pp. $53 \mathrm{ff}$.

35 On this disputed question, cf. P.-M. Gy, 'Der Tod des Christen' in Handbuch der Liturgiewissenschaft, vol. 2, Die übrigen Sakramente und die Sakramentalien. Die Heiligung der Zeit, ed. by A.-G. Martimort et al. (Freiburg, Basel, Vienna: Herder, 1965), pp. 164 ff.; on the other hand, see Franz-Joseph Dölger, Ichtys. Der Heilige Fisch in den antiken Religionen und im Christentum. Textband II (Münster i. W.: Aschendorf, 1922), p. 565: 'Es gewinnt also den Anschein, als ob die Lehre von der Erbsünde mitbestimmend gewesen wäre, um den Geburtstag der antiken Totenliturgie $z u$ verdrängen und ihn durch das Jahresgedächtnis des Todes zu ersetzen. Im Hintergrund steht aber das jüdische Jahrgedächtnis, das die stärkste Unterlage bot.' See also, however, the rejoinder to this statement, by Karpinski, Annnua dies dormitionis, p. 191 n. 1, who denies Old Testament examples of any of the anniversary rites in Christianity.

36 Cf. Karl J. Merk, Die messliturgische Totenehrung in der römischen Kirche. Zugleich ein Beitrag zum Mittelalterlichen Opferwesen, I. Teil (Stuttgart: Schloz, 1926), pp. 87-108; Ludwig Ruland, Die Geschichte der kirchlichen Leichenfeier (Regensburg: Manz, 1901), pp. $146 \mathrm{ff}$. For different rites and their intentions, cf. also Arnold Angenendt, 'Theologie und Liturgie der mittelalterlichen Toten-Memoria', in Memoria. Der geschichtliche Zeugniswert des liturgischen Gedenkens im Mittelalter, ed. by K. Schmid and J. Wollasch (Munich: Fink, 1984), pp. 79-199, esp. pp. $179 \mathrm{ff}$. 
innovations changed the character and status of the Catholic Church in medieval society, especially in southern Germany and Austria ${ }^{37}$.

Berthold of Regensburg, a famous ascetic, itinerant preacher and member of the Ordo Fratres Minores who died in 1272,38 provides an exemplar for this change. He seems to have paved the way, especially in southern Germany, the Danubian region, Bohemia, and Austria, for a new theology of ' $d o$, ut des' (I give, that you might give), that strongly emphasized the effects of prayers for the dead, specifically those recited in an anniversary mass, such as the Paternoster ('Our Father'), the Ave Maria ('Hail Mary') and the Credo (The Apostles' Creed). His German sermons, which are an important source for any reconstruction of the Volksfrömmigkeit - the piety of the common people - at that time, reflect a remarkable concern about death, and a growing interest in the whereabouts of souls in hell.

In one of his German sermons, that was edited posthumously by his adherents, we find that Berthold recommended praying three additional Paternosters silently, after the celebration of the mass. ${ }^{39}$

Three Paternosters in silence after the Paternoster [of the mass]: And he should say the first one to praise and honour almighty God and to praise and honour the Holy Mother, my Holy St. Mary, and all the heavenly armies; and the second Paternoster you should recite to honour almighty God, a blessing for all Christian people on earth; and a third Paternoster you should recite to comfort all souls and as a help for them in purgatory.

37 Cf. O. G. Oexle, 'Die Gegenwart der Toten', in - Death in the Middle Ages, ed. by H. Braet/ W. Verbke, Mediaevalia Lovaniensia I Studia IX (Leuven: Leuven University Press, 1983), pp. 19-77; Norbert Ohler, Sterben und Tod im Mittelalter (Munich, Zürich: Artemis, 1990), p. 37 and p. 129. G. Hölzle, 'damit och unser gedechtnus [...] nit mit dem glocken ton zergang'. 'Totengedenken in Bruderschaften Bayerisch Schwabens und Altbaierns anhand literarischer und liturgischer Quellen', in Totengedenken und Trauerkultur. Geschichte und Zukunft des Umgangs mit Verstorbenen, ed. by M. Herzog (Stuttgart, Berlin, Cologne: Kohlhammer, 2001), pp. 87-110; Karl Müller, 'Die Esslinger Pfarrkirche im Mittelalter', Württembergische Vierteljahrshefte für Landesgeschichte, Neue Folge, 16 (1907), pp. 237-326, esp. pp. 313-23; H. Lentze, 'Begräbnis und Jahrtag im mittelalterlichen Wien', Zeitschrift der Savigny-Stiftung für Rechtsgeschichte 67 Kanonistische Abteilung, 36 (1950), pp. 328-64.

38 On him, cf. F. G. Banta, Art. 'Berthold von Regensburg', in Die deutsche Literatur des Mittelalters. Verfasserlexikon, ed. by Kurt Ruh, vol. 1, Berlin, New York 1978, pp. 817-23.

39 Cf. Berthold von Regensburg. Ausgewählte Predigten. Mit einer Einleitung by H. Hering (Leipzig: Richter, 1893), p. 128 [on the mass]; Berthold von Regensburg. Vollständige Ausgabe seiner deutschen Predigten mit Anmerkungen und Wörterbuch by F. Pfeiffer, Vol. 1 (Vienna 1862, repr. Berlin: de Gruyter, 1862, pp. $501 \mathrm{f}$. On the literary difficulties of these sermons and their historical value, cf. also Werner Röcke, Berthold von Regensburg. Vier Predigten (Stuttgart: Reclam, 1983), pp. 235-64. 
The third Paternoster mentioned in this sermon is not known to older prayer orders, such as the commonly accepted Missale Romanum ${ }^{40}$. The slightly different Regensburger Missale ${ }^{41}$, notes that it should be said to comfort the souls of the believers and to save the souls of the departed in purgatory.

Similar additions to the standard prayer recitations may be found in many other Christian documents from that time. ${ }^{42}$ For example, in a Franciscan Missale from Southern Germany we find prescriptions for the seven Gregorian masses that stress the importance of fifteen sets of 'Pater noster cum totidem Ave Maria et Credo' for the dead. ${ }^{43}$ Of interest in this regard is also that the end of the fourteenth century, the sheer quantity of masses said for the dead dramatically increased. This is confirmed not only by the large number of donations usually connected with the reading of masses for the dead but also by the many last wills whose primary concern focuses on making reliable arrangements for reading such anniversary masses. ${ }^{44}$ This case in point is also affirmed in several documents from Wiener Neustadt, a place that is, as noted above, closely connected with the development of the reception of the term yahrzeit. Remarkably, in this small town, that might serve for many reasons as a typical model of a Catholic environment, the 'Jahrtag'-masses were held in high esteem by the public. 45

40 Vgl. Missale Romanum cum lectionibus III. Tempus per Annum Hebdomadae VI-XXI, (Vatican: Libr. Ed. Vaticana, 1977), pp. 1854 ff.; Die Feier der Heiligen Messe [Messbuch] für die Bistümer des deutschen Sprachgebietes. Authentische Ausgabe für den liturgischen Gebrauch, Teil II: Das Messbuch deutsch für alle Tage des Jahres außer der Karwoche (Linz: Herder, 1975), pp. 1129-34; Enchiridion Liturgicum Compectens Theologiae Sacramentalis et dogmata et leges iuxta novum codicem rubricarum, concinnavit P. Rado, Tomus Primus (Rom, Freiburg, Barcione: Herder, 1961), pp. 372 ff. For the older rites see M. Fearotin, Le Liber Ordinum. En Usage dans l'Église wisigothique et mozarabe d'Espagne du cinquième au onzième siècle, Bilbiotheca 'Ephemerides Liturgicae' Subsidia 83, Istrumenta Liturgica Quarreriensia 6 (Rom: Ed. Liturgiche, 1996), pp. 447 ff. [6.-8. cent.]; Judith Frei, Das Ambrosianische Sakramentar D 3-3 aus dem Mailändischen Metropolitankapitel. Eine textkritische und redaktionsgeschichtliche Untersuchung, Corpus Ambrosiano-Liturgicum 3 (Münster: Aschendorf, 1974), pp. 419 ff. [10. cent.]; Odilo Heiming, Corpus Ambrosiano Liturgicum I. Das Sacramentarium Triplex. Die Handschrift C 43 der Zentralbibliothek Zürich (Münster: Aschendorf, 1969), pp. 349-51.

41 Cf. Anton Beck, Kirchliche Studien und Quellen (Amberg: Bös, 1903), esp. pp. 246-54.

42 Cf., for example, Rieger in his review article on Elbogen, Gottesdienst, where he hints at a Nekrologium Monasterii S. Crucis Ratisbonensis. There we find written in Middle High German on fol. 229: 'Hie sint angeschriben die tôten, den wir gebunden sin, daz wir iarcit mit vigilien und mit messen alle iar begên.'

43 Cf. Adolf Franz, Die Messe im Deutschen Mittelalter. Beiträge zur Geschichte der Liturgie und des Religiösen Volkslebens (Freiburg i. B.: Herder, 1902), p. 257.

44 See Merk, Messliturgische Totenehrung, pp. 102-4.

45 Cf. Helga Skvarics, Volksfrömmigkeit und Alltagskultur. Zum Stiftungsgeschehen Wiener Neustädter Bürger im Spätmittelalter und in der frühen Neuzeit (14.-16. Jh.), Beiträge zur neu- 
The assumption that Jews who lived in a town like Wiener Neustadt would not have noticed any of the aforementioned changes and developments in their Christian environment in late thirteenth century seems not only to be naive, but arises out of an extremely uncritical picture of how Jews lived in a Christian environment. In a town like Wiener Neustadt, that housed a considerable Jewish population from the late thirteenth century until the expulsion in the mid-fourteenth century, Jews lived not in a ghetto, but in close proximity to their Christian neighbours. According to numerous documents from this location, Jews shared strong economic ties with their fellow residents and, despite all limitations, it is attested that the Jews also adopted local behaviours and customs. ${ }^{46}$

Is it therefore too far-fetched to assume that the inclusion of the qaddish at the anniversary of a death, as attested in Sefer Maharil (not yet kabbalistically re-interpreted), might have been influenced by its Christian environment?

Admittedly, it is impossible to prove whether Jews from Wiener Neustadt, or from similar places in Southern Germany and Austria, were directly influenced by their neighbours' mourning customs. Furthermore, it must, of course, be taken into consideration that at the end of the thirteenth century, the boundaries between the Christian and the Jewish hemisphere were not easily permeable. But even if we take into account the strong barriers between the Jewish and the Christian worlds at that time, one cannot totally deny the possibility of influences that sometimes left behind only slight traces, like, in our case, the remarkable adoption of the German word yahrzeit itself.

\section{Conclusion}

This study is best summed up with both cautions and evidence. With regard to the trace developments in Volksfrömmigkeit, research in this area necessarily remains shaky. For methodological reasons, it must be emphasized that inquiring into direct influences on local minhagim should always be considered a

eren Geschichte Österreichs 15 (Frankfurt a.M., Berlin, Bern, Brussels, New York, Oxford, Vienna: Lang, 2000).

46 On the close relationship between Jews and Christians in Wiener Neustadt during thirteenth century, cf. Martha Keil, Juden in Grenzgemeinden: Wiener Neustadt und Ödenburg im Spätmittelalter', in idem and E. Lappin (eds.), Studien zur Geschichte der Juden in Österreich, Handbuch zur Geschichte der Juden in Österreich, Reihe B, Vol. 3 (Bodenheim: Philo-Verlag, 1997), pp. 9-33, esp. pp. 15 ff. See also Germania Judaica, Vol. 3: 1350-1519, 2. Ortschaftsartikel Mährisch-Budwitz - Zwolle, ed. by A. Maimon/M. Breuer/Y. Guggenheim (Tübingen: Mohr, 1995), p. 1621. 
very problematic task. ${ }^{47}$ The use of the word 'influence' itself may be misunderstood in so far as it seems to involve directionality. Of course, one cannot speak of a Christian intention to change Jewish mourning practices. Rather, the use of that term here points to the fact that any environment leaves its imprint on culture, and, in this case, a majority of Christians may have had such an impact on a smaller group of Jews. ${ }^{48}$

In the case of the yahrzeit qaddish, the current sources are still so meagre that any definite answer of who adopted it, why they made that choice, or whether they were influenced by certain local customs remains guesswork. The development of a custom, such as the yahrzeit qaddish, cannot, however, be explained by intrinsic developments within the Jewish culture alone, particularly since these yahrzeit customs developed in Christian lands but not in the Islamic world.

As this paper aims to demonstrate, the custom of reciting qaddish on the anniversary developed from an older custom, the minhag of saying qaddish yatom. ${ }^{49}$ This disputed and often criticized custom of yahrzeit qaddish ${ }^{50}$ cannot, however, be fully understood on the basis of known explanations of this qaddish. Obviously the use of the qaddish as an annual prayer for mourners was widely accepted only after it was re-interpreted on the basis of kabbalistic thinking. But these concepts certainly do not reflect the original intention of saying qaddish on an anniversary; there is an evident gap in the chain of interpretation for saying the qaddish on the yahrzeit, that can best be explained by a lack of knowledge about the real motivations for this liturgical development. Thus, if we deal with this apparently 'very' Jewish custom, we can and must take into account that its development may also have been stimulated by a spiritual atmosphere and culture then dominated by the Catholic Christianity and by Volksfrömmigkeit, with its own cryptic ways of transmitting cus-

47 On a similar problem, which refers to the reconstruction of Christian 'influence' on an apparent Jewish motif, cf. Peter Schäfer, 'Daughter, Sister, Bride, and Mother: Images of the Femininity of God in the Early Kabbala', Journal of the American Academy of Religion, 68 (2000), pp. 221-42. See on this question also Peter Schäfer, Die Geburt des Judentums aus dem Geist des Christentums (Tübingen: Mohr-Siebeck, 2010), p. 178.

48 As already mentioned above, the use of candlelights for the commemoration of the dead also seems to have been a custom developed in a cultural environment where the use of candles was common. See on this very custom an overview cited by Katrin Seidel, Die Kerze. Motivgeschichte und Ikonologie (Hildesheim, Zürich, New York: Olms, 1996), pp. 67-73. For an uncritical study of the Jewish use of lights, see the article by Oppenheimer, mentioned above, n. 12.

49 Cf. already Moshe Isserles on Shulhan 'Arukh, Yore De'a, 376.4 [Hilkhot Avelut] (299b).

50 See on this, e.g., Jakob J. Petuchowski, Prayerbook Reform in Europe. The Liturgy of European Liberal and Reform Judaism (New York: World Union for Progressive Judaism, 1968), pp. $324 \mathrm{ff}$. 
toms and religious practices. People during the time focused on in this study were very concerned about the afterlife and the well-being of the dead. This intense preoccupation, so typical of Christian belief during that period, seems to have left its mark by introducing an additional qaddish among its neighbours, the Jews. 